\title{
Religious Situation and Buryat Identity
}

\author{
Irina E. Yelaeva* \\ Institute for Mongolian, \\ Buddhist and Tibetan Studies SB RAS \\ 6 Sakhyanovoi, Ulan-Ude, 670047, Russia
}

Received 30.10.2013, received in revised form 28.04.2014, accepted 17.09.2014

This article is devoted to the analysis of the relationship of the religiosity and Buryat identity; the historical context of the formation of the modern religious situation in Buryatia, which, in turn, has an impact on the religious practices of the Buryats, is given; peculiarities of religious and confessional identity of the Buryats are considered.

Keywords: religious situation; religiosity; Buryat identity; religious identity; confessional identity.

Research area: philosophy, culture studies, sociology.

Buryatia is the multinational region. More than a hundred nationalities live in the Republic and it explains uniqueness, variety and diversity of culture. Many religions of the world are represented in Buryatia. On this earth time has interwoven its inimitable pattern of nationalities and languages, customs and beliefs.

\section{Historical context}

The most ancient faith is Shamanism. There were rather complex relations between ancient inhabitants of Baikal region and surrounded mountains, forests, lakes and rivers. All geographical places had their own deities «ezhins»-patrons of area.

The peculiar feature of the Buryat shamanism is the developed polytheism, the multiple hierarchy of deities and spirits «ezhins», «khats», «zayans», «ongons» etc. Structurally, the Buryat shamanism is a unity of religious beliefs, religious psychology, cult system, religious relations, institution of shamans, shamanic folklore and art [Mikhailov, 1987, pp. 258-259]. Some ritual ceremonies are kept by present day, for example, wayfarer pays tribute to sacred places - «obo», «barisa» during long travel.

In the XVII ${ }^{\text {th }}$ century a wide spreading of Buddhism and Christianity began.

Buddhism was officially recognized by the Russian government in 1741 year: Empress Elizabeth issued a decree about legal status of the Buddhist clergy. According to this decree, the government officially permitted the Buddhist monks religious sermons and other activities among the Buryats.

The first Orthodox Church in Buryatia Spaso-Preobrazhenskaya - was built in 1648 year on the territory of the first fortress in Buryatia Barguzinskii ostrog, founded by Russian

(c) Siberian Federal University. All rights reserved

* Corresponding author E-mail address: rine12007@yandex.ru 
Cossacks under the leadership of Ivan Galkin (Zhalsaraev, 2001, pp. 10-11).

Old Believers began to move to Transbaikalia in the second half of the XVIII ${ }^{\text {th }}$ century from Starodubje and Vetka, which were part of that time in Poland, where the old believers had gone from prosecutions by not having taken the church reforms of Patriarch Nikon. The Old Believers of Transbaikalia got the name «Semeiskie» because they were deported to Transbaikalia with their own families, as opposed to single-exiles (Bolonev, 1994, p. 60]. In 1777 year the first Old Believers Chapel in Buryatia was opened in Novaya Bryan village (Petrova, 2005, p. 156).

In the second half of the XIX ${ }^{\text {th }}$ century the beginning of the $\mathrm{XX}^{\mathrm{th}}$ century because of the development of trade, gold mining, and, particularly, the construction of the TransSiberian railway the influx of new settlers acquired a mass character. Increased migration has changed religious situation, confessional structure became more diverse. Religious tolerance of local population, tolerant relations between people of different faiths favored to the emergence of new religious communities. For example, in Verkhneudinsk in 1882 year the synagogue was built (Zhalsaraev, 2011, p. 183), in September 1907 the mosque was opened
(Zhalsaraev, 2011, p. 228) and on July, 24th, 1909 the Catholic church was consecrated (Zhalsaraev, 2011, p. 233).

As of 1922, on the territory of two BuryatMongolian Autonomous areas within the Russian Soviet Federative Socialist Republic and the Far Eastern Republic, formed on May, 30th, 1923 the Buryat-Mongolian Autonomous Soviet Socialist Republic, confessions were distributed in the following way (see Table 1):

During the period from the repressions (1930-s years) till 1945, there was no functioning temple in operation in Buryatia. All Buddhist temples-datsans, Orthodox churches, Old believer's churches and other temples belonging to other religious communities have been closed; invaluable Cult objects have been destroyed or plundered. But the hardest fate has befallen keepers of faith: clerics have been executed or exiled. In 1945, considering merits of Buddhist clergy and believers in fund raising for needs of Red Army, the Buddhist temple Ivolginskii Datsan was established. The same 1945 year, the Svyato-Voznesenskaya Orthodox Church was opened in Ulan-Ude (From the history of religious confessions of Buryatia..., 2001, pp. 150-151). At the end of 1940-s years Old Believer's community has been registered in the village Novyi Zagan of the Mukhorshibirskii rural district (From the

Table 1. Confessional structure in 1922 (Shagdurov, 1998, pp. 69-70).

\begin{tabular}{|l|c|c|c|c|}
\hline \multicolumn{1}{|c|}{ Confession } & $\begin{array}{c}\text { Religious } \\
\text { communities }\end{array}$ & Cult buildings & $\begin{array}{c}\text { The number } \\
\text { of priests }\end{array}$ & $\begin{array}{c}\text { The number } \\
\text { of believers }\end{array}$ \\
\hline Orthodoxy & 311 & 154 & 137 & 83234 \\
\hline Buddhism & 46 & 46 & 7419 & 77830 \\
\hline Old Believers & 81 & 81 & 81 & 22700 \\
\hline Judaism & 7 & 7 & 7 & 460 \\
\hline Islam & 6 & 5 & 5 & 91 \\
\hline $\begin{array}{l}\text { Evangelical } \\
\text { Christians-Baptists }\end{array}$ & 5 & 5 & 1 & 80 \\
\hline Catholicism & 1 & 1 & & \\
\hline
\end{tabular}


history of religious confessions of Buryatia..., 2001, p. 155).

\section{Point}

Last two decades were included into Russian history not only as the period of global transformations of the country and the society as a whole, but it was also the time of deep and dramatic shocks for each family, each person. In the situation of deconstruction of habitual life practices, changes of social standards, introduction of new models of social achievement, and, as a consequence, crisis of identity, people began to search alternative concepts and institutional forms which would allow to restructure and constitute social space on new paradigms and to find the lost sense of psychological comfort and a stable social status. On this background the special importance was got by ethnic identity.

One of the ways of the analysis of everyday ethnicity is the defining of what markers function as ethno-identifying determinants. It has been revealed that the dominant positions in the system of ethno-defining attributes of the Buryat identity still belong to the culturally-oriented features. According to the results of our ethno-sociological researches, the fourth place in the Buryat ethnic identification structure is occupied by the marker «Buddhism» (1996-1997 mass survey - 35,2 percents of the respondents-Buryats, 2002-2003 mass survey - 46,7\%, 2006 mass survey $55,9 \%)$.

Within the latest years, in scientific literature and mass media much attention has been given to the phenomenon of religious revival. Peter $\mathrm{L}$. Berger coined the phrase «desecularization of the world» to describe this phenomenon. He gave two explanations of the origins of worldwide resurgence of religion: «One: Modernity tends to undermine the taken-for-granted certainties by which people lived through most of history. This is an uncomfortable state of affairs, for many an intolerable one, and religious movements that claim to give certainty have great appeal. Two: A purely secular view of reality has its principal social location in an elite culture that, not surprisingly, is resented by large members of people who are not part of it but who feel its influence... Religious movements with a strongly anti-secular bent can therefore appeal to people with resentments that sometimes have quite nonreligious sources» (Berger, 1999, p. 11).

From the psychological point of view, the increasing importance of religion, obviously, is caused by its protective and compensatory functions, because religion is capable of compensating real discomfort from life problems and of giving feeling of psychological security to the individual.

Religious renaissance is usually analyzed in the context of the following circumstances: firstly - the role and the place of religion in modern society and state, secondly - the increase of interest to religion in population as a whole, and, thirdly - the growth of number of adherents of these or those confessions. As Bryan S. Turner wrote, «with this eruption of the religious in the public sphere, the notion that modern societies are secular has been seriously challenged and various alternatives to secularization have been proposed, such as de-secularisation, re-sacralisation and the emergence of a post-secular society. In the modern world, religion, contrary to conventional understanding of the process of modernisation as necessarily entailing secilarisation, continues to play a major role in politics, society and culture» (Turner, 2011, p. X).

Exploring modern religious phenomena, it is necessary, in my opinion, to distinguish different aspects of their functioning: institutional, discursive and personal. The institutional aspect of the analysis is focused on consideration of religion as a social institution. The discursive aspect assumes textual analysis of renovation 
rhetoric and discourses of legitimating of religious institution. The personal aspect is associated with research of religious identity and it is focused on studying forms, structures, and dynamics of religious identity.

\section{Example}

Today the historical and cultural memory of the Buryats and other peoples of the Baikal region are actively recalled, the national selfconsciousness is growing, the traditional religions - Shamanism, Buddhism, Orthodoxy and Old believing - are reviving, new religious organizations have appeared, there was a significant increase in the number of adherents of all faiths. Thus, current situation in the field of religion and religiosity is characterized as pluralistic and it is determined by broad variety of confessions and religious organizations. In terms of market approach based upon rational choice theory, there is developed market of religious goods and services.

If in the beginning of 1990-s there were 4-5 religious organizations in Buryatia (Newspaper «Buryatia». 1996. October, 18), by January, 1st, 2014, 214 religious organizations (Information about the work of the Ministry of Justice of Russia in the sphere of state registration and control over the activity of religious organizations for 2013) were registered, including:

- 63 Buddhist temples and communities (including Damba Darzha Zayayev Buddhist University «Dashi Choynkhorlin» which was opened in 1991 year. On June, 16th, 1999 it received a state license to conduct educational activity in the sphere of higher religious education). Traditionally, the Gelugpa school of Tibetan Buddhism is widely spread in Buryatia. More than half of the existing datsans are part of the Buddhist traditional Sangha of Russia. Along with this, there are Buddhist communities who are followers of other schools, such as Karma Kagyu, Nyingmapa, Dzogchen;

- 74 parishes and monasteries of the Russian Orthodox Church (the Buryat Deanery was formed in March 1994. At first it was a part of the Irkutskaya and Chitinskaya Diocese of the Russian Orthodox Church. With the restoration of the Chitinskaya and Zabaikalskaya Diocese in 1994, the Buryat Deanery came under its jurisdiction. The UlanUdenskaya and Buryat Diocese was established by decision of the Holy Synod of the Russian Orthodox Church on October, 10th, 2009);

- 9OldBeliever's churches and communities (including Russian Orthodox Old Belief Church (Belokrinitskaya Hierarchy) - 4, Russian Old Orthodox Church (Novozybkovskaya Hierarchy) - 5);

- 9 religious organizations of Shamans;

- 1 Roman Catholic church,

- 1 Muslim mosque,

- 1 Judaic community,

- 26 churches and communities ofChristians of Evangelical Faith - Pentecostals,

- 4 communities of Evangelical ChristiansBaptists,

- 5 communities of Evangelical Christians,

- 7 Presbyterian churches and communities,

- 2 community of Seventh Day Adventists,

- 2 Jehovah's Witnesses organizations,

- 1 Church of Jesus Christ of Latter-day Saints (Mormons),

- 1 New Apostolic Church,

- 1 Lutheran Church (Inkerin EvankelisLuterilainen Kirkko),

- 1 center of International Society for Krishna Consciousness,

- 1 community of the Bahá'i Faith, 
- 5 other religious organizations.

Recently due to active missionary networks, non-conventional for the given region religious communities have appeared, for example, Presbyterian Church, The Church of Jesus Christ of Latter-day Saints (Mormons), International Society for Krishna Consciousness, Bahá'i Faith and some others. Popularity of new religious movements in Buryatia and confusion or mixing of ideas and practices from different religious systems in everyday life under the influence of culture of subjectivism (religion has increasingly become the matter of individual choice, and person can combine and construct his or her «patchwork religion» like «patchwork quilt» (P. Wuthnow, 1998, p.2)) show not only the tolerance of the local population, but also allows speaking about growing advancement of «modern spirituality» unlike «traditional religion» (Heelas, Woodhead, 2005). The sacred persists but not necessarily in traditional forms. Even analysing traditional religion such as Christianity, Grace Davie has coined the phrase «believing without belonging» to describe many people in Britain today who are the Christians but seldom or never go to church or to characterize people who declare themselves as religious but they can't identify with any existing religious institution (Davie, 1994). In recent writings she uses the refined term «vicarious religion» because relation between believing and belonging has become more complex and diverse, for example, unchurched people delegate their belief to church, religious leaders and active parishioners. By vicarious, she means «the notion of religion performed by active minority but on behalf of a much large number, who (implicitly at least) not only understand, but quite clearly approve what minority is doing» (Davie, 2008, p. 169). Stated differently, there is wide range of different forms and manifestations of «new» vitality of religion.
One more peculiarity of religious situation is that the number of evangelical organizations of various institutional affiliations has been essentially increased. It should be stressed that these organizations are popular not only among Russian speaking people but also among the Buryats. D. Martin, explaining the global advance of Evangelism in the world, wrote that «initially there was a tendency to pigeonhole Evangelical expansion as a form of American cultural imperialism, supported by American money and spearheaded by American missionary personnel, including the televangelists. However, most resent research recognizes that, whatever the origins of some of these movements in the North Atlantic Protestant world, they are now independent and indigenous in both personnel and finance. In contemporary world of mass communications and geographical mobility, the missionary is no longer necessary. Missioners exist, of course, but even if they did not the Evangelical expansion would be much the same, given the capacity of religious messages to pass along lines of personal and familial contact» (Martin, 1999, p. 38). These religious associations give humanitarian aid and gifts for its members (most active members can get financial support to participate in training seminars in Russian and foreign religious centers), organize free English language courses for all comers.

To regulate relations in the field of human rights to freedom of conscience and freedom of religion, as well as the legal status of religious associations, the following normative documents were made:

- on October, 25th, 1990, the Law of RSFSR № 267-1 «About freedom of religions» was adopted;

- on December, 26th, 1995, the President of the Republic of Buryatia L.V. Potapov signed the Decree of the President of the Republic of Buryatia № 297 «About 
the establishment of the Council for cooperation with religious associations under the President of the Republic of Buryatia»;

- on May, 21st, 1996, the President of the Republic of Buryatia L.V. Potapov signed the Decree of the President of the Republic of Buryatia «About the concept of state-church relations in the Republic of Buryatia»;

- on September, 26th, 1997, the Federal Law № 125-FZ «About freedom of conscience and about religious associations» was adopted;

- on December, 23d, 1997, the Law of the Republic of Buryatia № 610-I «About religious activity on the territory of the Republic of Buryatia» was adopted;

- on September, 19th, 2002, President of the Republic of Buryatia L.V. Potapov signed the Decree of the President of the Republic of Buryatia № 198 «About the establishment of the Council for cooperation with religious associations under the Head of the Republic of Buryatia», according to which the new «Regulations of the Council for cooperation with religious associations under the Head of the Republic of Buryatia» was approved;

- on November, 30th, 2010, the Federal Law № 327-FZ «About transfer of property for religious purposes, which is in state or municipal ownership, to religious organizations» was adopted.

Religious identity. The concept of «religious identity » has many rich and varied interpretations. Religious identity in the most general meaning can be defined as the reference to the individual itself to believers. Substantially, in religious identity, from the psychological viewpoint, it is possible to point out three components: cognitive, affective and regulatory. The cognitive component is expressed in the realization of himself as a believer, and it also implies certain religious knowledge, perceptions of his religious affiliation. The affective component is associated with the whole complex of feelings and experiences that color the religious views and often manifest themselves in emotionally rich variants of worship to God. The regulatory component puts a person in the field of religious activity and considers him or her as the agent of religious practice. The real behavior of the believer is defined by his attitude to God. There are a number of rules and customs associated with manners in places of worship and using of sacred objects. Moreover, among believers another system of decision-making is formed. Believers accept religious values and norms and they are guided by special system of decision-making which they think as the behavior approved by God.

Thus, I think that, in the concretized sense, religious identity can be regarded as awareness by the individual of an affiliation to his own religious community, accompanied by the world-outlook and emotional-value acceptance of basic principles and doctrinal concepts of given religious system and manifests itself by a certain (religious) behavior in situations with the expressed religious context (Yelaeva, 2003, p. 168).

The idea of religious unity of members of ethnic community is one of the most important components of the Buryat ethnic identity. Moreover, there was an increase in the number of the Buryats who consider themselves to be believers (see below the results of our ethnosociological researches - Table 2), which in turn suggests enhancing the role of religion as personally accepted marker of the Buryat ethnicity.

Confessional identity. Answering the question about one's confessional affiliation, the 
Table 2. The number of the Buryats who declare themselves to be believers, $\%$.

\begin{tabular}{|l|l|l|l|}
\hline & \multicolumn{1}{|c|}{$1996-1997$} & \multicolumn{1}{|c|}{$2002-2003$} & \multicolumn{1}{|c|}{2006} \\
\hline Yes, the believer, I try to observe customs and rituals & $41 \%$ & $48,3 \%$ & $59,4 \%$ \\
\hline The believer, but I do not observe customs and rituals & $22,2 \%$ & $30,5 \%$ & $21,2 \%$ \\
\hline The doubting & $15,4 \%$ & $7,9 \%$ & $6,5 \%$ \\
\hline The unbeliever & $9,4 \%$ & $7 \%$ & $11,2 \%$ \\
\hline It is hard to answer & $12 \%$ & $6,3 \%$ & $1,2 \%$ \\
\hline
\end{tabular}

majority of respondents referred to themselves as Buddhists, the rest of respondents - as Shamanists or as adherents of other religions. A part of respondents identified themselves as both Buddhists and Shamanists. They said that they asked for advise to both Buddhist monkslamas and shamans. In order to ask for well-being respondents perform Buddhist and shamanic rituals. Some respondents declared themselves at once as Buddhists, Shamanists and Orthodox believers. Therefore it is the phenomenon of syncretism of religious practices (one point needs stressing: it should not be confused with patchwork religion), which has been a result of joint inhabitancy and cultural interaction between the Buryats and the Russians for a long time.

For this reason it has become essential to investigate the Buryat ethnic identity in a context of mutual influence of different systems of values, for example, Eastern and Western in global cultural meaning, or Buddhist, Shamanistic and Orthodox which are present simultaneously in public consciousness and everyday social practices of the Buryats.

But despite the intensity of the process of religious revitalization and highly enough level of religiosity of the Buryat people, my ethnosociological researches have shown that religious identity has not yet become very subjectively significant status characteristic for the majority of the population, for this reason it occupies not especially essential position in the group structure of the identification preferences (sixth place in the hierarchy of social identities) of the Buryats.

Therefore it is correct to differentiate actual religious and cultural components in religious identity (Ryzhova, 2010, p. 60). It seems to me that two hypostasis of religious identity have to be designated: religious identity as personal value and religious identity as the following tradition (Yelaeva, 2003, p. 169).

In other words, for many adherents of this or that confession religious identity has no achievable value and it has only the ascribed status. For such believers religious identity is only outwardly attributed group membership, but not interiorized value orientation, that is, some people consider themselves, for example, to be Buddhists according to nominal signs, in particular, because their parents declare themselves to be Buddhists or because Buddhism is recognized by them as the national religion and so on. For example, among the answers to the question «If you are a believer, what religion do you refer yourselves» there were not infrequently the definitions confirming manifestation of religiosity as the following tradition: «to Buryat [religion]», «to local religion», «to national Buryat religion».

Religion is perceived as an inalienable part of ethno-national culture that implicitly implies formal (nominal) belonging to the prescribed («ethno-national») religion without any necessity of choice. Religion is an instrument and a way of ethnic socialization. In such a context, religious 
practice is not so conscious and purposeful religious activity but in the greatest degree it is unconscious and natural, in a sense, habitual or accustomed renewal of religion as a social institution. Following Michael Billig's definition of «banal nationalism» (Billig, 1995, pp. 5-9), Russell Sandberg styles such religiosity as «banal religiosity». The concept of «banal religiosity» denotes a mindset that clings on to religion simply as a vague moral source of identity. Like Billig's concept of «banal nationalism», banal religiosity is constantly perpetuated by everyday habits. It is a civic religion based upon basic ethical principles traditionally aligned with religious traditions which has grown as a response to religious difference. The concept of «banal religiosity» allows us to draw attention to the powers of an ideology which is so familiar that is hardly seems noticeable (Hill, 2012, p. 324).

Frequently in recent time pragmatic relation to religion has been encountered, there were situations when people are included in the religious forms of activity only by virtue of necessity, they perform ritual and rite which have concrete situational and highly vital sense for them. People resort to the help of religion most often in the cases of illness. I agree with Bryan S. Turner that «in modern societies, religion has been both democratized and commercialized with growth of megachurches, TV evangelism, drive-in confessions, buy-aprayer, religious tourism and what I have called «low intensity religion». Religion survives in Immanuel Kant's terms not so much as reflective faith but more as health and wealth cults offering a range of services to a variety of this-worldly needs of human beings» (Turner, 2010, p. 651).

In modern Buryat society the nominal belonging to a religious community («belonging without believing», reversing the famous phrase) is more spread than actual religiosity.
On the other hand, the following tradition, participation in rituals, experience of incorporation with religious history and heritage of its own people can be the first step for a person to understanding and adoption of value (moral) postulates of religious doctrine. For example, at the present day lectures for all comers on Buddhist doctrine and practice given by Buddhist lamas - teachers of Buddhist University have become more popular. As well by means of ritual the person has the possibility of familiarizing with sacred senses and the relations not having direct utilitarian value.

\section{Conclusion}

Religious and ethnic, indeed, are very closely connected with each other (more vividly it is manifested when analyzing modern cultural creativity and religious discourses). In the situation of ethnic mobilization religion was frequently used by ethnic elites (including Buryat) as the legitimate form of their consolidation. Here a question arises about the boundaries between ethnicity and religion. As Craig R. Prentiss has rightly emphasized, «the social construction of racial and ethnic categories involves much more than the mythologies and rituals of religious traditions. In many, if not all cases, these social boundaries grew out of profoundly complex economic, political, technological, and educational circumstances. But among those circumstances, religion has often been a vital factor, and ... any account of the social construction of race and ethnicity will be incomplete if it fails to consider the influence of religious traditions and narratives» (Prentiss, 2003, p. 2).

Moreover, in some countries and regions religion has crucial importance, so it may be said without exaggeration that religious absorbs ethnic, more especially in public sphere («political religion»). In Buryatia ethnicity prevails over 
religiousness. Religion plays a conceptual and functional role of a marker of ethnic culture and identity. Religion has become the resource of preservation and revival of ethnic originality. Legitimization of religion by ethnic elite has promoted the strengthening of symbolical social function of religion as a marker of Buryat ethnicity.

At the same time, in the context of ethnicity religious orientations and religious behavior are the sign manifestation of intra-and intergroup interaction. Religion carries out an essential integrating function thanks to which the association of believers in some macrosocial community takes place. Belonging to given religion supports a feeling of solidarity in believers and thus enhances the strengthening of stability of the religious community. The idea of religious unity is one of the principal components of ethnic identity. However in the situation of ethnic mobilization religion is a not merely ethnic identification criterion, at the foreground symbolic function acts: religion as ethnic symbol.

\section{References}

1. Berger P.L. The Desecularization of the World: A Global Overview // The Desecularization of the World: Resurgent Religion and World Politics / Edited by Peter L. Berger. Wm. B. Eerdmans Publishing, pp. 1-18.

2. Billig M. Banal Nationalism. London: Sage, 1995. 200 p.

3. Bolonev F.F The Old Believers of Transbaikalia in the XVIII-XX centuries [Staroobryadtsy Zabaikal'ya v XVIII-XX vv.]. Novosibirsk: AOZT «Publishing house FEBRUARY», 1994. $148 \mathrm{p}$.

4. Davie G. Religion in Britain Since 1945: Believing Without Belonging. Oxford: Blackwell, 1994. $244 \mathrm{p}$.

5. Davie G. From Believing without Belonging to Vicarious Religion: Understanding the Patterns of Religion in Modern Europe // The Role of Religions in Modern Societies / Edited by Detlef Pollack and Daniel V. A. Olson. New York: Routledge, 2008, pp. 165-176.

6. From the history of religious confessions of Buryatia. XX century. Collection of documents [Iz istirii religioznykh konfessii Buryatii. XX vek. Sbornik dokumentov]. Ulan-Ude: Committee on Affairs of archives of the Republic of Buryatia, 2001. 260 p. +16 sheets of illustrations.

7. Heelas P., Woodhead L. The Spiritual Revolution: Why Religion is Giving Way to Spirituality. Oxford: Wiley-Blackwell, 2005. 226 p.

8. Hill M. Bracelets, Rings and Veils: The Accommodation of Religious Symbols in the Uniform Policies of English Schools // Law, Religious Freedoms and Education in Europe / Edited by Myriam Hunter-Henin. Ashgate Publishing, Ltd, 2012, pp. 307-326.

9. Information about the work of the Ministry of Justice of Russia in the sphere of state registration and control over the activity of religious organizations for 2013 [Svedeniya o rabote Minjusta Rossii v sfere gosudarstvennoi registratsii I kontrolya za deyatel'nost'iu religioznykh organizatsii za 2013 god], Available at: http://to04.minjust.ru/sites/to04.minjust.ru/files/page/2014/01/81_093_1312.xls (accessed 3 March 2014).

10. Martin D. The Evangelical Upsurge and Its Political Implications // The Desecularization of the World: Resurgent Religion and World Politics / Edited by Peter L. Berger. Wm. B. Eerdmans Publishing, pp. 37-50. 
11. Mikhailov T.M. Buryat Shamanism: History, Structure and Social Functions [Buryatskii shamanizm: istoriya, struktura i sotsial'nye funktsii]. Novosibirsk: Nauka, 1987. 288 p.

12. Newspaper «Buryatia». 1996. October, 18.

13. Petrova E.V. Modern Transbaikalian Old Belief: ethnosociological analysis: Study Guide [ Sovremennoe zabaikal'skoe staroobryadchestvo: etnosotsiologicheskii analiz: Uchebnoe posobie]. Ulan-Ude: Publishing House of Buryat State University, 2005. 184 p.

14. Prentiss C.R. Introduction // Religion and the Creation of Race and Ethnicity: An Introduction / Edited by Craig R. Prentiss. New York and London: New York University Press, 2003, pp. 1-12.

15. Ryzhova S.V. The making of Russian orthodox identity: traditional cultural and civic bases [Stanovlenie pravoslavnoi identichnosti russkikh: traditsionno-kulturnye i grazhdanskie osnovaniya] // Sociological Studies [Sotsiologicheskie issledovaniya]. 2010, pp.59-69.

16. Shagdurov IU.P. The State and Religious Confessions of Buryatia in the 1920- 30-s years (Gosudarstvo i religioznye konfessii Buryatii v 1920-1930 gg.). Studies in the History of Siberia, Central and Eastern Asia [Issledovaniya po Sibiri, Tsentral'noi i Vostochnoi Azii]. Ulan-Ude: Publishing House of Buryat State University, 1998, pp. 65-82.

17. Turner B.S. Religion in a Post-secular Society // The New Blackwell Companion to the Sociology of Religion / edited by Bryan S. Turner. Oxford: Wiley-Blackwell, 2010, pp. 649-667.

18. Turner B.S. Religion and Modern Society: Citizenship, Secularisation and the State. Cambridge University Press, 2011. 344 p.

19. Wuthnow R. After Heaven: Spirituality in America Since the 1950s. Berkeley, Los Angeles, London: University of California Press, 1998. 286 p.

20. Yelaeva I.E. Religious Identity of Buryats (Religioznaya identichnost' buryat). Buddhism in the Context of the History, Ideology and Culture of Central and Eastern Asia: Proceedings of International Scientific Conference [Buddizm v kontekste istorii, ideologii i kul'tury Tsentral'noi i Vostochnoi Azii: Materialy mezhdunarodnoi nauchnoi konferehtsii]. Ulan-Ude: Publishing House of Buryat Scientific Center of Siberian Branch of Russian Academy of Sciences, 2003, pp. 166-170

21. Zhalsaraev A.D. Settlements, Orthodox churches, priests of Buryatia of the XVII-XX centuries: encyclopedic reference book [Poseleniya, pravoslavnye khramy, svyashchennosluzhiteli Buryatii XVII-XX stoletii: entsiklopedicheskii spravochnik] Ulan-Ude: Buryat book publisher, 2001. 448 p.

22. Zhalsaraev A.D. Time. Events. People. The chronological list of the dates and the facts from the history of ethnic Buryatia (the Paleolithic era - 2010 year) [Vremya. Sobytiya. Liudi. Khronologicheskii perechen' dat i faktov iz istorii etnicheskoi Buryatii (epokha paleolita - 2010 god)]. Ulan-Ude: Publishing house JSC «Republican printing house», 2011. 408 p.: ill. 


\section{Религиозная ситуация \\ и идентичность бурят}

И.Э. Елаева

Институт монголоведения, буддологии и тибетологии СО РАН Россия, 670047, Улан-Удэ, ул. Сахьяновой, 6

Статья посвящена анализу взаимоотношений религиозности и этнической идентичности бурят; дан исторический контекст формирования современной религиозной ситуаиии в Бурятии, которая, в свою очередь, оказывает влияние на религиозные практики бурят; рассмотрены особенности религиозной и конфессиональной идентичности бурят.

Ключевые слова: религиозная ситуачия; религиозность; этническая идентичность бурят; религиозная идентичность; конфессиональная идентичность.

Научная спеииальность: 09.00.00 - философские науки, 24.00.00 - культурология, 22.00.00 соииологические науки. 